\title{
Variability and trends in Laptev Sea ice outflow between 1992-2011
}

\author{
T. Krumpen ${ }^{1}$, M. Janout ${ }^{1}$, K. I. Hodges ${ }^{2}$, R. Gerdes ${ }^{1}$, F. Girard-Ardhuin ${ }^{3}$, J. A. Hölemann ${ }^{1}$, and S. Willmes ${ }^{4}$ \\ ${ }^{1}$ Alfred Wegener Institute, Busse Str. 24, 27570 Bremerhaven, Germany \\ ${ }^{2}$ National Center for Earth Observation, Harry Pitt Building, 3 Earley Gate, Reading, RG6 6AL, UK \\ ${ }^{3}$ Spatial Oceanography Laboratory, French Research Institute for Exploration of the Sea, Pointe du Diable \\ 29280 Plouzane, France \\ ${ }^{4}$ Department of Environmental Meteorology, University of Trier, Behringstr. 21, 54286 Trier, Germany
}

Correspondence to: T. Krumpen (thomas.krumpen@awi.de)

Received: 13 June 2012 - Published in The Cryosphere Discuss.: 27 July 2012

Revised: 29 January 2013 - Accepted: 29 January 2013 - Published: 28 February 2013

\begin{abstract}
Variability and trends in seasonal and interannual ice area export out of the Laptev Sea between 1992 and 2011 are investigated using satellite-based sea ice drift and concentration data. We found an average total winter (October to May) ice area transport across the northern and eastern Laptev Sea boundaries (NB and EB) of $3.48 \times 10^{5} \mathrm{~km}^{2}$. The average transport across the NB $\left(2.87 \times 10^{5} \mathrm{~km}^{2}\right)$ is thereby higher than across the EB $\left(0.61 \times 10^{5} \mathrm{~km}^{2}\right)$, with a less pronounced seasonal cycle. The total Laptev Sea ice area flux significantly increased over the last decades $\left(0.85 \times 10^{5} \mathrm{~km}^{2}\right.$ decade $\left.^{-1}, p>0.95\right)$, dominated by increasing export through the EB $\left(0.55 \times 10^{5} \mathrm{~km}^{2} \mathrm{decade}^{-1}, p>\right.$ 0.90 ), while the increase in export across the NB is smaller $\left(0.3 \times 10^{5} \mathrm{~km}^{2} \mathrm{decade}^{-1}\right)$ and statistically not significant. The strong coupling between across-boundary SLP gradient and ice drift velocity indicates that monthly variations in ice area flux are primarily controlled by changes in geostrophic wind velocities, although the Laptev Sea ice circulation shows no clear relationship with large-scale atmospheric indices. Also there is no evidence of increasing wind velocities that could explain the overall positive trends in ice export. The increased transport rates are rather the consequence of a changing ice cover such as thinning and/or a decrease in concentration. The use of a back-propagation method revealed that most of the ice that is incorporated into the Transpolar Drift is formed during freeze-up and originates from the central and western part of the Laptev Sea, while the exchange with the East Siberian Sea is dominated by ice coming from the central and southeastern Laptev Sea. Furthermore, our results imply that years of high ice export in late winter (February to May) have a thinning effect on the ice cover, which in
\end{abstract}

turn preconditions the occurence of negative sea ice extent anomalies in summer.

\section{Introduction}

In recent years, the summer Arctic sea ice extent and thickness have undergone dramatic changes. The total sea ice extent is declining at an annual rate of approximately $3 \%$ per decade over the satellite record (1978 to present), and the summer sea ice decline seems to be accelerating (Kwok and Rothrock, 2009; Kwok et al., 2009; Comiso, 2010; Stroeve et al., 2011). Following Kwok and Rothrock (2009), the thickness of sea ice decreased by $64 \%(1.6 \mathrm{~m})$ between 2003 and 2008 compared to early submarine measurements that were made between 1958 and 1976. The rapid reduction in Arctic summer ice extent and thickness is assumed to result from anomalously high surface air temperatures (Stroeve et al., 2005) and changes in the large-scale atmospheric circulation (Meier et al., 2007).

Climate models agree that the sea ice extent and thickness will further decline through the 21st century in response to atmospheric greenhouse gas loading (Zhang and Walsh, 2006; Stroeve et al., 2012; Massonnet et al., 2012). Furthermore, ice drift and deformation increase and net ice growth rates decrease (Spreen et al., 2011; Rampal et al., 2009). To determine associated changes in the Arctic sea ice volume requires consideration of changes in ice volume fluxes that appear at the major gates of the Arctic, such as Fram Strait. A positive trend in Fram Strait sea ice export was found for the first time by Smedsrud et al. (2011). The authors used 


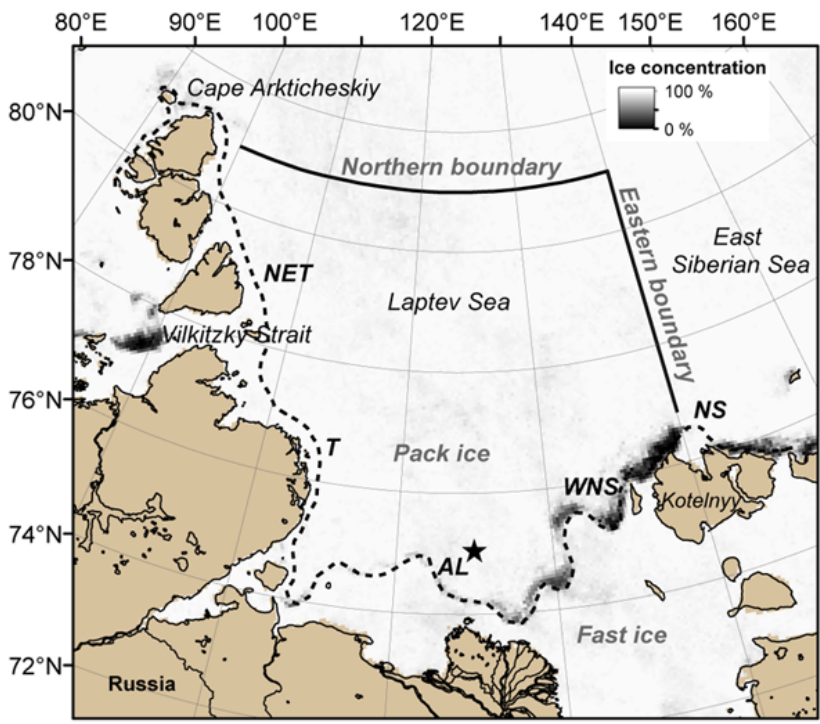

Fig. 1. The geographical location of the Laptev Sea and the northern and eastern boundaries (solid black lines) on which meridional and zonal ice area flux estimates are based. The dashed line represents the mean fast ice edge location. Between pack ice and fast ice edge, flaw polynyas are formed: the New Siberian polynya (NS), the Western New Siberian polynya (WNS), the Anabar-Lena polynya (AL), the Taymyr polynya and the Northeastern Taymyr (NET) polynya. Color coding corresponds to the sea ice concentration as obtained from Advanced Microwave Scanning Radiometer (AMSR-E) on 7 May 2008 (source: IUP Bremen, Spreen et al., 2008a). The position of the moorings used for satellite ice motion data validation are indicated by black stars.

geostrophic winds derived from reanalysis data to calculate the ice area export between Spitsbergen and Greenland and estimated it to be about $25 \%$ larger than during the 1960s. Whether Fram Strait volume fluxes are decreasing, or if the reduction in sea ice thickness is capable of compensating for the observed increased ice export out of the Arctic is currently under discussion.

Understanding changes that appear at the major flux gates requires a closer look at the origin of the ice leaving the Arctic Ocean. It is assumed that a substantial part of the Fram Strait export is formed in the Siberian shelf seas, connected with Fram Strait via the Transpolar Drift. Among the Siberian shelf seas, the Laptev Sea is considered one of the most significant regions of net ice production and export (Zakharov, 1966a; Dethleff et al., 1998). It is very shallow, with water depths between 15 and $200 \mathrm{~m}$ (Timokhov, 1994), and comprises an area of approximately $500 \times 10^{3} \mathrm{~km}^{2}$. The Laptev Sea is located between the coast of Siberia, Severnaya Zemlya and the New Siberian Islands (Fig. 1), and is icecovered from October to June (Bareiss and Goergen, 2005). The ice cover can be divided into three regimes: the fast ice, the pack ice, and flaw polynyas (Eicken et al., 2005). The freely floating ice pack offshore the fast ice edge consists mainly of ice formed during fall. According to systematic observations carried out by the Soviet Union since the 1930s, it reaches a mean thickness of $1.57 \mathrm{~m} \pm 0.25 \mathrm{~m}$ (Romanov, 1996). The pack ice drift is dominated by persistent offshore winds leading to a continuous export of ice out of the Laptev Sea into the basin and/or the East Siberian Sea (Timokhov, 1994; Rigor and Colony, 1997).

Rigor and Colony (1997) found by means of a combination of modeling results and observations that as much as $20 \%$ of the ice transported through Fram Strait is produced in the Laptev Sea, giving it a key role in the future fate of the Arctic sea ice. The seasonal and interannual variability of sea ice exchange with the surrounding seas was first examined by Zakharov (1966b, 1967). Following Alexandrov et al. (2000), their estimates are based on average monthly gradients of atmospheric pressure across the northern and northeastern Laptev Sea boundaries and revealed a mean winter sea ice area transport of approximately $3.3 \times 10^{5} \mathrm{~km}^{2}$. Alexandrov et al. (2000) investigated ice area fluxes by means of a numerical model and found flow rates of $4.83 \times 10^{5} \mathrm{~km}^{2}$ per winter. In addition, a number of studies examine sea ice circulation patterns and their linkage to atmospheric and oceanic forcing on shorter timescales (e.g. Rigor and Colony, 1997; Eicken et al., 1997; Haas and Eicken, 2001).

Given the importance of the Laptev Sea for the Arctic Ocean sea ice budget, the aim of this paper is to update previous estimates of ice exchange between the Laptev Sea and the surrounding seas. Since we are lacking ice thickness information, the investigation is limited to the determination of area fluxes derived from state-of-the-art satellite ice motion and ice concentration information. Below we examine how the ice export in the Laptev Sea changed throughout the past two decades and identify the governing mechanisms controlling ice exchange with the surrounding seas. Furthermore, we investigate the role of atmospheric forcing for observed trends in ice transport.

The structure of the paper is as follows. A description of the satellite data used to derive ice fluxes along the Laptev Sea boundaries is given in Sect. 2. In addition, the accuracy of the dataset is determined through a comparison with high resolution satellite data and mooring observations. In Sect. 3, we analyze seasonal and interannual flux rates across boundaries and identify the origin of sea ice leaving the Laptev Sea in late winter. In Sect. 4 we discuss results and relate fluctuations in winter ice export to changes in atmospheric circulation patterns, as well as to sea ice anomalies in summer. Conclusions are drawn in Sect. 5.

\section{Dataset description and validation}

The ice area flux out of the Laptev Sea into the Transpolar Drift and East Siberian Sea is calculated based on ice drift velocities and ice concentration at the northern boundary (NB) 


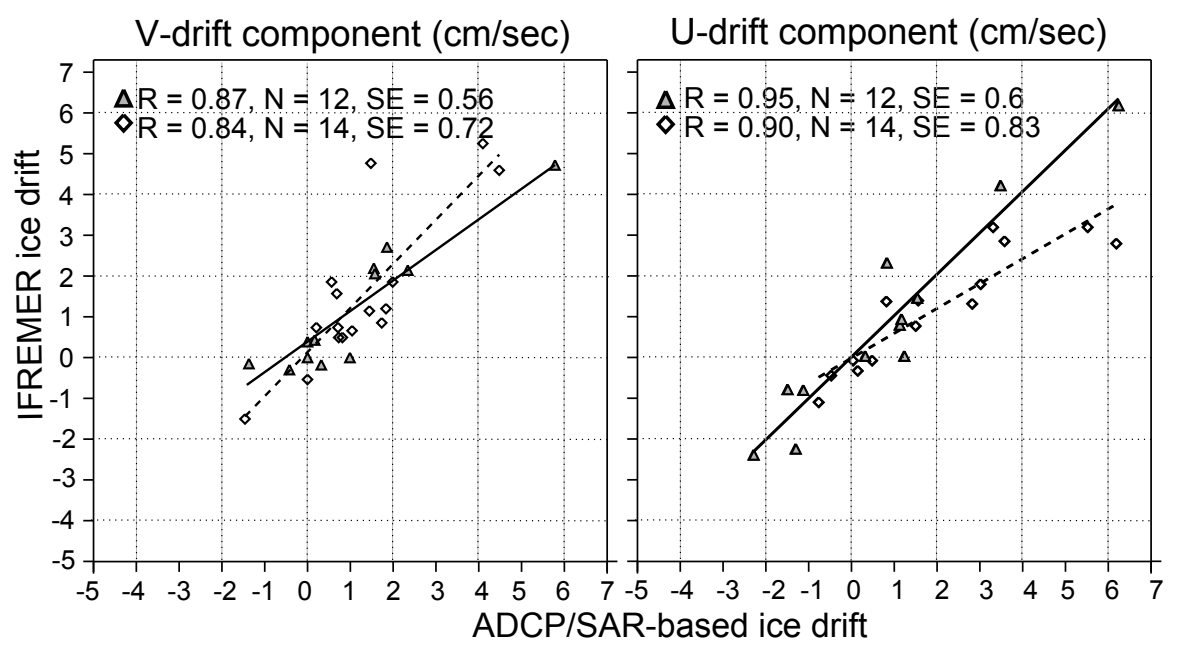

Fig. 2. Comparison between monthly mean Ifremer ice motion estimates and Envisat SAR (triangles) and ADCP based (diamonds) monthly mean ice drift. The $U$ and $V$ drift components are shown in the left and right panel, respectively. The solid and dashed line show the linear fit between Ifremer data and SAR and ADCP estimates. SAR motion information is based on a selection of scenes taken between 2006 and 2010 (December to April), while ADCP ice drift data originate from 3-yr round moorings (2007-2009) deployed in the vicinity of the fast ice edge. In addition, the correlation coefficient $(R)$, number of samples $(N)$, and standard deviation $(S E)$ is given.

and eastern boundary (EB) of the study region (Fig. 1). The NB spans a length of $700 \mathrm{~km}$ and is positioned at $81^{\circ} \mathrm{N}$, between Cape Arkticheskiy and $140^{\circ} \mathrm{E}$. The EB, with a length of $460 \mathrm{~km}$, connects the eastern end of the NB with Kotelnyy $\left(76.6^{\circ} \mathrm{N}, 140^{\circ} \mathrm{E}\right)$. For easier comparison, our northern and eastern boundaries are equivalent to those boundaries used by Alexandrov et al. (2000).

\subsection{Sea ice drift dataset}

Sea ice drift can be estimated using various techniques between time lag satellite images (e.g. Emery et al., 1991; Kwok and Rothrock., 1999; Girard-Ardhuin and Ezraty, 2012). Ice drift information obtained from satellites has been applied in various studies to examine Arctic-wide spatial trends in sea ice drift velocity and area flux (e.g. Kwok, 2009; Spreen et al., 2011). In particular during winter months, when the atmospheric moisture content is low and surface melt processes are absent, the quality of the drift estimates is high. Restrictions may arise from the spatial resolution of the sensors in near-shore regions characterized by a complex coastline, extensive fast ice areas, and polynyas.

The accuracy of ice drift data in the Laptev Sea was investigated by Rozman et al. (2011) through a comparison with in situ measurements. The best performance was found in the ice drift product provided by the European Space Agency (ESA) via the Center for Satellite Exploitation and Research (CERSAT) at the Institut francais de recherche pour l'exploitation de la mer (Ifremer), France. Hence, in the following the Ifremer data set is used to calculate winter fluxes at the NB and EB. The motion fields are available on an operational level from 1 September until the end of May, cov- ering the period from 1992 to present. They are based on a combination of drift vectors estimated from scatterometer data (the National Aeronautics and Space Administration SeaWinds/QuikSCAT for 1992-2009 period, and the European Advanced Scatterometer (ASCAT)/MetOp for 2009 to present) and radiometer data (the $85 \mathrm{GHz}$ channel data of Special Sensor Microwave Imager SSM/I on-board the Defense Meteorological Satellite Program, available since 1992). The data are available on a polar stereographic grid with a grid size of $62.5 \mathrm{~km}$, using time lags of 3 days. Details about processing and validation of these data can be found in Girard-Ardhuin and Ezraty (2012).

\subsection{Accuracy of sea ice drift data}

As an additional quality control we compare the Ifremer motion estimates with monthly ice drift information obtained from Environmental Satellite (Envisat) Synthetic Aperture Radar (SAR) images (Fig. 2). Ice drift information from Envisat SAR scenes can be easily extracted by identifying identical ice flows on consecutive images. In this study, monthly ice drift information from Envisat wide swath (WS) scenes were obtained in areas near the NB and EB from images covering the beginning and end of April 2004, December and January 2007, January to May and December 2008, February and December 2009, and February to March 2011. The Envisat C-band WS data is VV polarized and covers an area of approximately $400 \times 400 \mathrm{~km}^{2}$ with a spatial resolution of $150 \times 150 \mathrm{~m}^{2}$ (Krumpen et al., 2011b,a). Overall 12 monthly ice drift estimates are available. The comparison with the Ifremer dataset was done by interpolating Ifremer estimates to the locations of SAR ice drift retrieval. The 
agreement between Ifremer data and manually extracted Envisat ice drift information is high for both the zonal $(U)$ and meridional $(V)$ ice drift components (correlation coefficient $R=0.87$ and 0.95 , Fig. 2). The estimated standard deviation (SE) for the Ifremer ice drift velocity is $0.56 \mathrm{~cm} \mathrm{~s}^{-1}$ for $V$ and $0.6 \mathrm{~cm} \mathrm{~s}^{-1}$ for the $U$ drift components. For comparison, the uncertainty in ice drift velocity reported by Rozman et al. (2011) is around $1 \mathrm{~cm} \mathrm{~s}^{-1}$ for the Laptev Sea.

As stated earlier, the accuracy of passive microwave drift products may be reduced in near-shore areas. However, in Sect. 3 we identify the origin of sea ice leaving the Laptev Sea in late winter by means of a backtracking approach. Therefore the quality of the Ifremer data in shore areas is checked through a comparison with ice drift estimates taken from long-term moorings equipped with Acoustic Doppler Current Profilers (ADCP). The moorings were deployed between 2007 and 2009 near the fast ice edge in the southeastern Laptev Sea (for exact position see Fig. 1). The sampling frequency of the device is 30 minutes with a beam width (footprint) of $5 \mathrm{~m}$. An in-depth description of the mooring design and ADCP processing is given in Hoelemann et al. (2011) and Janout et al. (2012). In prior comparisons, the monthly mean ice drift was calculated from the ADCP data, and Ifremer drift data was interpolated to the mooring position. The correlation between Ifremer and ADCP data is slightly lower (Fig. 2, $R=0.84$ and 0.9 for $U$ and $V$ ) with a higher standard deviation $\left(0.72 \mathrm{~cm} \mathrm{~s}^{-1}\right.$ for $V$ and $0.83 \mathrm{~cm} \mathrm{~s}^{-1}$ for $U$ ). The limited number of samples included in this comparison and the differences in spatial and temporal sensor resolutions may impact the reliability of the comparison. In addition, the presence of fast ice, the complex coastline and the occurrence of polynyas are restricting factors. Nevertheless, the high agreement shows that Ifremer data is capable of producing ice drift in near-coastal Laptev Sea areas correctly.

\subsection{Sea ice concentration}

The ice concentration data used in this paper are also made available by Ifremer (Ezraty et al., 2007). The product is based on $85 \dot{\mathrm{GHz}} \mathrm{SSM} / \mathrm{I}$ brightness temperatures, using the ARTIST Sea Ice (ASI) algorithm developed at the University of Bremen (Spreen et al., 2008b). The use of the $85 \mathrm{GHz}$ channel data enables a sea ice concentration at $12.5 \mathrm{~km} \times 12.5 \mathrm{~km}$ pixel resolution.

\subsection{Sea ice area flux estimates at the Laptev Sea boundaries}

Following Kwok (2009), the meridional and zonal ice area flux at the NB and EB, respectively, is the integral of the product between the $V$ and $U$ component of the ice drift and ice concentration. Initially, ice motion vectors were interpolated to the $12.5 \mathrm{~km}$ ice concentration grid. In the following, a positive (negative) sign refers to an export out of (import into) the Laptev Sea. Transport (flux) rates are given in $\mathrm{km}^{2}$.

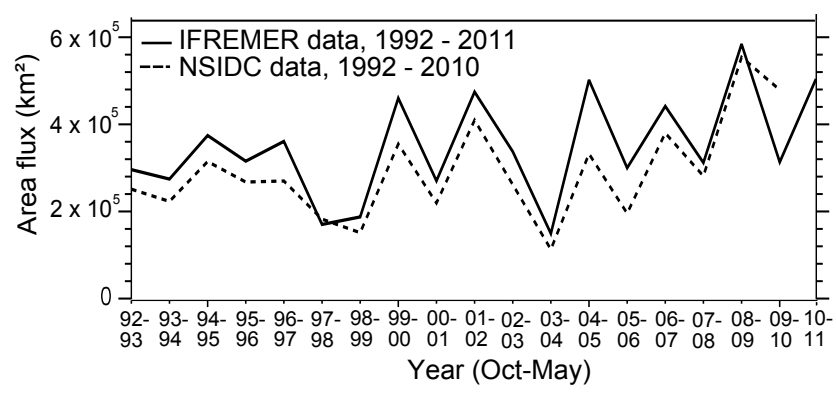

Fig. 3. Comparison between cumulative winter (October to May) Ifremer (solid line) and NSIDC (dashed line) total ice area flux estimates (given in $10^{5} \mathrm{~km}^{2}$ ) through the northern and eastern boundaries.

The sum of the meridional and zonal ice area flux across NB and EB is referred to as the total ice flux. After removing the seasonal cycle, trends were calculated in a least square sense, and significance at the $95 \%$ confidence level $(p)$ was measured using the Student's t-test following Kwok (2009). Please see Kwok and Pang (2004) and Kwok (2009) for a more detailed method description and error analysis.

\section{Results}

We present ice flux estimates at the northern and eastern Laptev Sea boundaries computed from Ifremer ice drift information. In order to assess the relative consistency and to quantify the importance of Laptev Sea ice export for the total Arctic sea ice budget, the results are compared with flux estimates from NSIDC drift data (Fowler, 2003) and export rates through Fram Strait (Smedsrud et al., 2011). In the following, we analyze the interannual and seasonal variability of meridional and zonal area fluxes through $\mathrm{NB}$ and $\mathrm{EB}$, and relate the observed fluctuations to changes in sea level pressure (SLP) gradients across the boundaries. Finally, the origin of the sea ice contributing to the annual export is examined through a backtracking approach of sea ice leaving the Laptev Sea in early spring.

\subsection{Laptev Sea ice area flux}

Figure 3 compares the cumulative winter (October to May) total ice area flux from 1992-2011 through the NB and EB calculated from Ifremer ice drift and concentration data, with estimates based on NSIDC drift data and Ifremer ice concentration information (see Sect. 2.3). The ice drift data, provided by the NSIDC (Fowler, 2003), are computed from Advanced Very High Resolution Radiometer (AVHRR), SSM/I and IABP buoy data. Information is given at a higher spatial resolution $(25 \mathrm{~km}$ grid) but is only available until 2010. Figure 3 shows that NSIDC flux estimates are lower than those from Ifremer $\left(2.91 \times 10^{5} \mathrm{~km}^{2} \pm 1.13 \times 10^{5} \mathrm{~km}^{2}\right.$ vs. $3.39 \times 10^{5} \mathrm{~km}^{2} \pm 1.17 \times 10^{5} \mathrm{~km}^{2}$ ). A comparison of the 


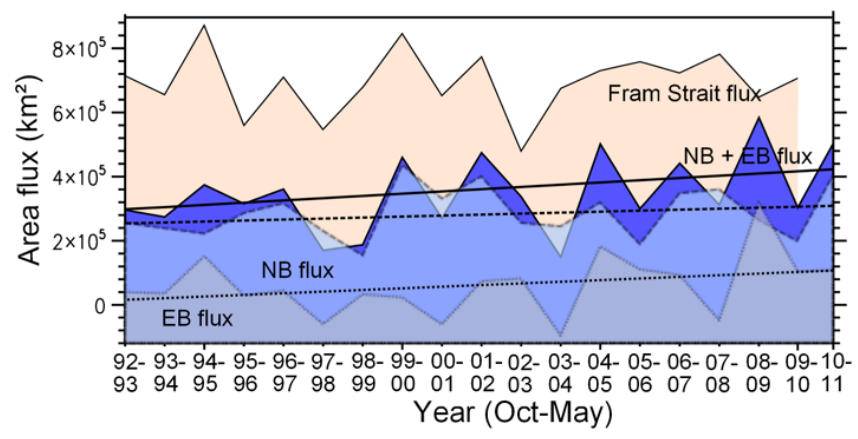

Fig. 4. Cumulative winter (October to May) ice area flux across the northern boundary (NB flux: dashed line, light blue filling), eastern boundary (EB flux: dotted line, grey filling) and northern and eastern boundaries (NB + EB flux: solid line, blue filling) between 1992 and 2011. Trend lines for total ice area flux (solid trend line, $0.85 \times 10^{5} \mathrm{~km}^{2} \mathrm{decade}^{-1}$ ), zonal flux across EB (dotted trend line, $0.55 \times 10^{5} \mathrm{~km}^{2}$ decade $^{-1}$ ) and meridional flux across NB (dashed trend line, $0.3 \times 10^{5} \mathrm{~km}^{2}$ decade $^{-1}$ ) are plotted on top. For quantitative comparison, the Fram Strait flux (solid line, beige filling) as calculated by Smedsrud et al. (2011) is shown.

NSIDC dataset with the SAR- and ADCP-derived drift information (see Sect. 2.2) reveals that NSIDC drift vectors generally underestimate observed drift velocities (not shown here). This is in agreement with findings made by e.g., Schwegmann et al. (2011) in the Antarctic. According to the authors, $71 \%$ of the NSIDC drift velocities are significantly lower than those observed by buoys. Nevertheless, the high correlation between NSIDC and Ifremer data $(R=0.82)$ gives confidence about the relative consistency of the Ifremer data.

The interannual variability of the total ice transport is shown together with the zonal and meridional component in Fig. 4. The net total winter transport is positive, but estimates show considerable interannual variability with the lowest rates occurring in winters of 1997/98, $1998 / 99$ and 2003/04 and the highest export in the winters of 2004/05 and 2008/09. The average total winter ice flux amounts to $3.48 \times 10^{5} \mathrm{~km}^{2}$ with a standard deviation (SE) of $1.2 \times 10^{5} \mathrm{~km}^{2}$. The average transport across EB $\left(0.61 \times 10^{5} \mathrm{~km}^{2} \pm 0.97 \times 10^{5} \mathrm{~km}^{2}\right)$ is generally lower than that across NB $\left(2.87 \times 10^{5} \mathrm{~km}^{2} \pm 0.78 \times 10^{5} \mathrm{~km}^{2}\right)$. However, with respect to the length of our boundaries and mean flux, the zonal transport exhibits larger fluctuations, with years being characterized by a net import from the East Siberian Sea (2007/08, 2000/01, 2003/04 and 2007/08). Note that there is a statistically significant positive trend in the total Laptev Sea ice area flux across the boundaries of $0.85 \times 10^{5} \mathrm{~km}^{2}$ decade $^{-1}(p>0.95)$. The trend in zonal export across EB is smaller (and $0.55 \times 10^{5} \mathrm{~km}^{2} \mathrm{decade}^{-1}$ ) and significant only at the $90 \%$ confidence level. The positive trend of the meridional export $\left(0.3 \times 10^{5} \mathrm{~km}^{2}\right.$ decade $\left.^{-1}\right)$ across NB is not statistically significant. Our Laptev Sea ice export estimates amount to nearly $48 \%$ of the winter (Fig. 4)

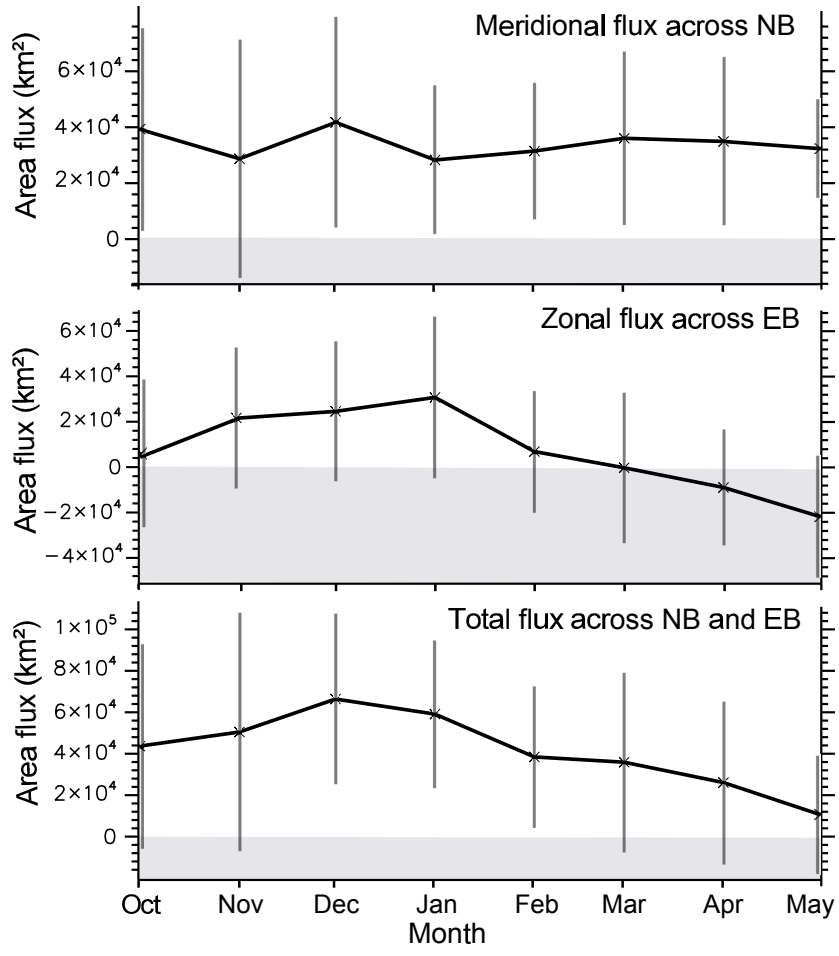

Fig. 5. Seasonal cycle of average monthly meridional ice area flux across northern boundary (upper panel), zonal flux across eastern boundary (center panel) and total flux (lower panel, given in $10^{4} \mathrm{~km}^{2}$ ) for the period between 1992 and 2011. Bars denote SE. Grey shaded areas correspond to ice inflow (negative flux).

and $41 \%$ of the annual export rates through Fram Strait. Fram Strait area flux estimates were taken from Smedsrud et al. (2011). Different to our approach, the authors derived ice area transport rates from radar satellites and SLP differences. Note that no significant correlation was found between Fram Strait and Laptev Sea outflows $(R=0.32)$.

The monthly averages of the total ice area flux (October to May) show a pronounced seasonal cycle with highest values between November and January and lowest flux rates in April and May (Fig. 5). The pronounced seasonal cycle is the consequence of a highly variable zonal transport across EB that attains its maximum in January and becomes negative in spring (April and May), corresponding to an ice import from the New Siberian Sea. The seasonal cycle of the meridional transport across the NB is relatively constant throughout the season and does not show large monthly variations.

The normalized monthly anomalies in the total Laptev Sea ice flux rates across NB and EB (Fig. 6) were calculated by dividing the difference between monthly total ice flux and the 19-yr monthly means by the 19-yr monthly standard deviations. A trend analysis of the time series revealed an increase in ice transport rates during all months. However, trends are significant at $95 \%$ confidence level only for January and March. Nevertheless, understanding the observed 
increase in total ice flux rates between 1992 and 2011, requires examining fluxes across the NB and EB separately. In Fig. 7 the average monthly ice concentration, ice drift velocity, ice area flux and sea level pressure (SLP) gradients are shown with the corresponding trends across the NB and EB between 1992 and 2011. The ice drift velocity represents the boundary-perpendicular component $(U$ and $V$ ). The monthly mean SLP gradients across the boundaries provide a measure of the strength of the geostrophic wind component. The SLP gradients are the difference between the eastern and western end of the NB and northern and southern end of the EB. Gradients were calculated using monthly mean SLP data from the National Centers for Environmental Prediction (NCEP)/Department of Energy (DOE, Kalnay et al., 1996). Southerly and westerly winds (positive gradients) results in ice export at the NB and EB, respectively, while negative gradients represent northerly and easterly winds and ice import across the NB and EB. Two representative examples of SLP distributions were chosen to highlight the location of atmospheric pressure systems and their impact during months with above and below-average ice export (Fig. 8). A positive SLP gradient across the NB is favored by the location of a high pressure system over the East Siberian Sea, resulting in an anticyclonic circulation, i.e. increased offshore winds (Fig. 8a). A displacement of the high pressure cell to the south introduces a westward component north of the New Siberian Islands and a positive SLP gradient across the EB. In contrast, the formation of a high pressure cell in the central Arctic suppresses ice export across boundaries (Fig. 8b).

Figure 7 suggests that the overall positive trend in January and March total ice area flux (Fig. 6 and description in text) is the consequence of a significant increase in ice flux across the EB in January and NB in March, respectively. Interestingly during September and October, when the average ice concentration has undergone a dramatic decrease throughout the last decade, the ice export across the NB is increasing, rather than decreasing. The fact that negative trends in the ice concentration are not seen in the ice area flux rates is explained by the balance between an increase in ice drift velocities during September and October and the decrease in ice coverage. Changes in the ice drift velocity in all months are in turn reflected in changes in the SLP gradient. The agreement between variations in the SLP gradients and ice velocities is $R=0.92$ for the NB and slightly lower $(R=0.81)$ for the EB. The strong coupling between across-boundary SLP gradient and ice drift velocity apparent in each month indicates that monthly variations in ice area flux are primarily controlled by changes in the magnitude of the geostrophic winds. In particular along the NB, positive or negative trends in ice drift rates between November and May are the consequence of positive or negative trends in SLP gradients. However, along the EB, trends in SLP gradients and ice drift rates coincide less or are even of opposite sign (for example November and December). Variations in SLP gradients still explain year-to-year changes in monthly zonal ice transport

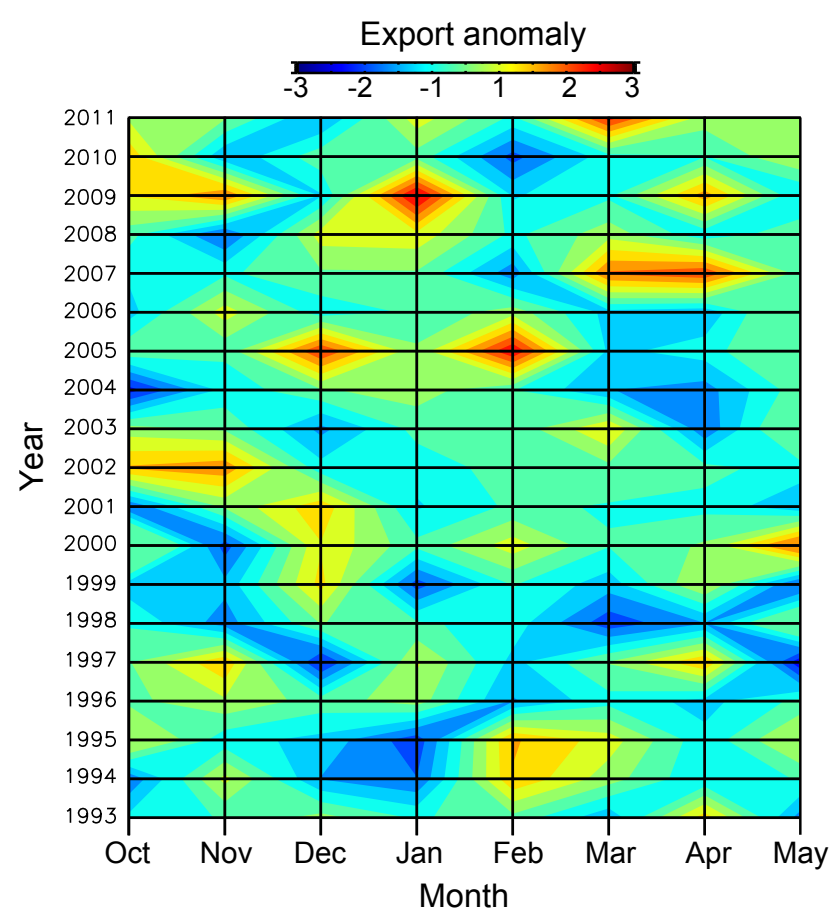

Fig. 6. Normalized monthly total ice area flux anomalies between October and May (1992-2011).

rates, but do not account for observed trends in drift rates. Here, changes in the internal ice state and/or ocean forcing may be responsible for the observed trends in drift and ice area transport rates. This is discussed in more detail in Sect. 4.

\subsection{Laptev Sea ice pathways}

To identify the sources and pathways of the sea ice, we backtracked ice crossing the NB and EB at the end of April for a 6-month period between 1992 and 2011. The drift analysis is limited to the winter months (beginning November until the end of April), when temperatures are below freezing and ice production takes place in flaw polynyas along the extensive fast ice belt (Fig. 1).

Figure $9 \mathrm{a}$ and $\mathrm{b}$ show the ice drift pathways for a year with high (winter of 2008/09) and low (winter of 1998/99) ice flux rates across boundaries. For describing the variability in the pathways, we analyzed the length and the displacement of ice leaving the Laptev Sea in April through the center of the NB and EB. The trajectories for winter of 2008/09 and 1998/99 are shown in Fig. 9a and b as black lines. The lengths of the trajectories indicate the net displacement of an ice parcel throughout the 6 month period. The average length of the pathway passing the center of the NB between 1992 and 2011 is $1046 \mathrm{~km} \pm 188 \mathrm{~km}$. The net displacement of the ice passing through the center of the EB is on average $9 \%$ shorter with a higher standard deviation $(956 \mathrm{~km} \pm 233 \mathrm{~km})$. 
a) Northern boundary
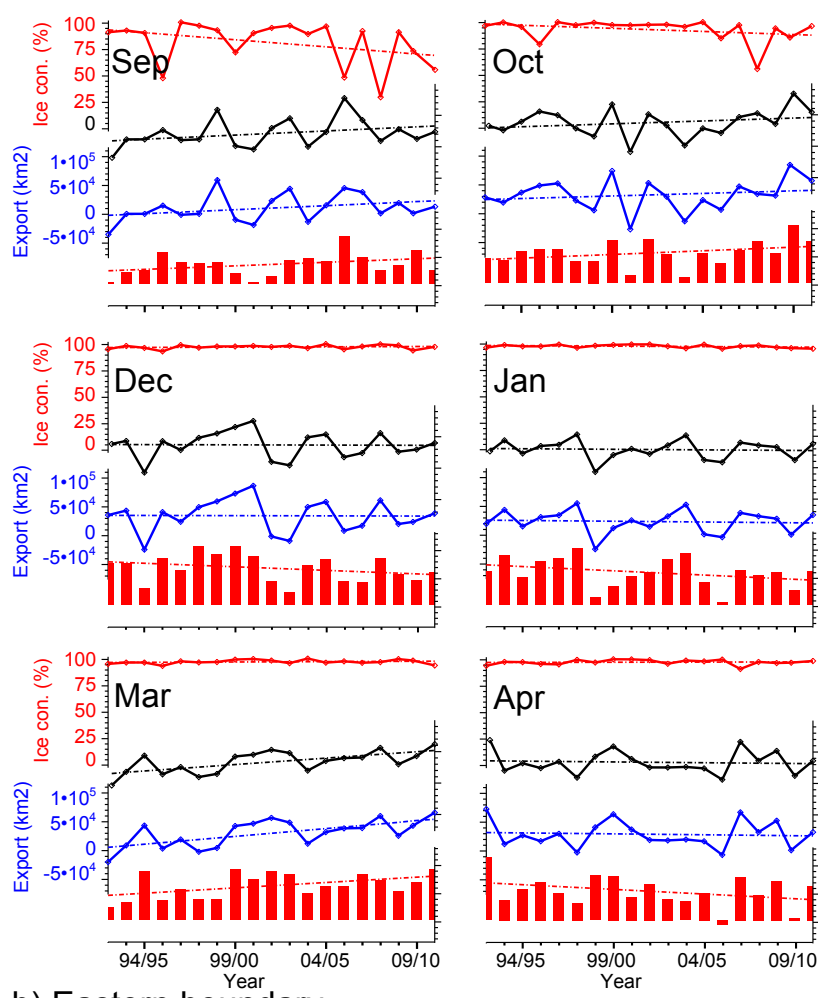

b) Eastern boundary
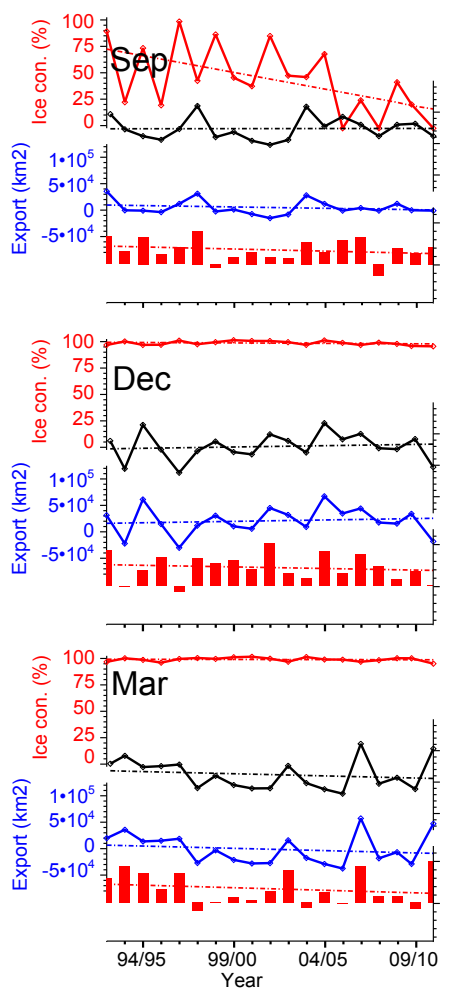
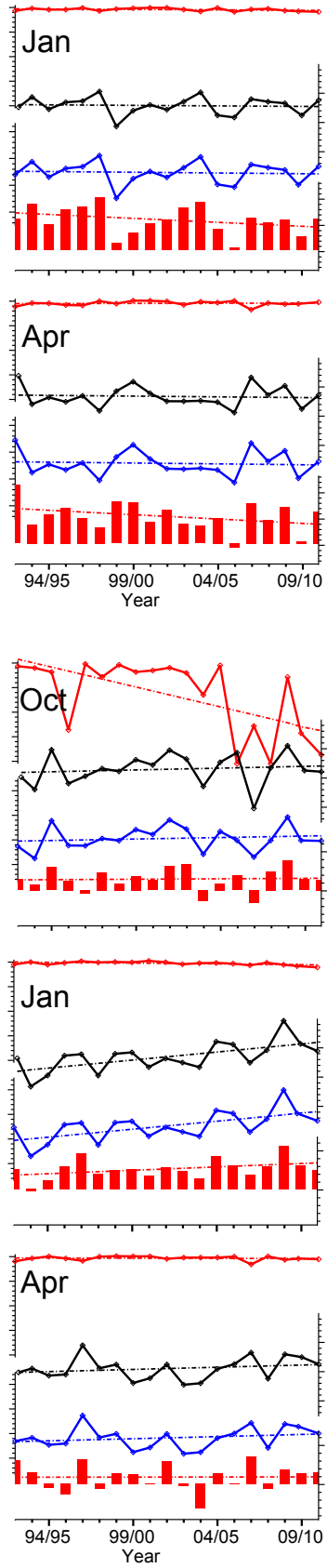
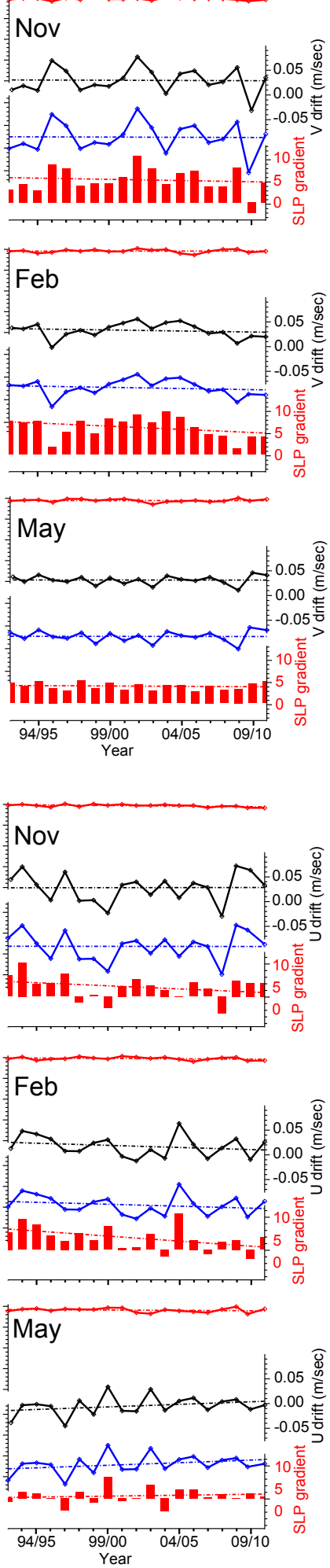

Fig. 7. Time series and trends of average monthly ice concentration, ice drift, ice area flux and sea level pressure gradient across northern boundary (a) and eastern boundary (b) between 1992 and 2011. The average monthly ice concentration is represented by the red line (upper left axis, given in \%). The cross-boundary monthly ice $\operatorname{drift}\left(V\right.$ and $U$ component for (a) and (b) given in $\mathrm{cm} \mathrm{s}^{-1}$, black line) and the monthly ice area flux (given in $10^{4} \mathrm{~km}^{2}$, blue line) refer to the upper right and lower left axis, respectively. The cross-boundary sea level pressure gradient (given in $\mathrm{hPa}$, lower right axis) is indicated by the red bars. 


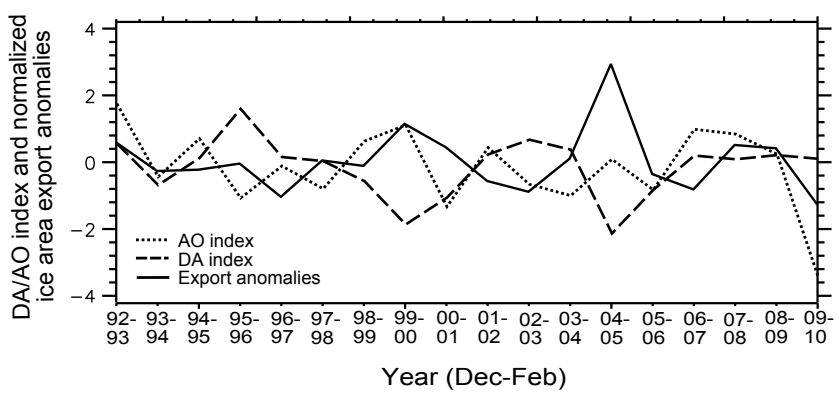

Fig. 8. Sea level pressure fields (mb) for a month of comparatively high (a) March 2007 and low ice area flux rates (b) April 1998 and across the northern and eastern boundary.

Maximum displacement of ice crossing the NB and EB were obtained in the winter of 2006/07 with $1550 \mathrm{~km}$ and $1407 \mathrm{~km}$, respectively. Lowest rates occurred in the winter of 1998/99 with $610 \mathrm{~km}$ (EB) and $744 \mathrm{~km}$ (NB). On average, the ice leaving the Laptev Sea through the central NB originates from the western Laptev Sea at $77.7^{\circ} \mathrm{N}\left( \pm 1^{\circ}\right), 118^{\circ} \mathrm{E}\left( \pm 8^{\circ}\right)$. Quantities within parentheses are standard deviations. The origin of ice passing through the center of the EB is located further southeast at $75.7^{\circ} \mathrm{N}\left( \pm 1^{\circ}\right), 132^{\circ} \mathrm{E}\left( \pm 11^{\circ}\right)$. Hence, most of the ice that is incorporated into the Transpolar Drift originates from the central and western part of the Laptev Sea, while the exchange with the East Siberian Sea is primarily dominated by ice coming from the central and southeastern Laptev Sea. Figure 9c presents the frequency distribution map of the origin of sea ice (positions of ice in November) calculated from pathways between 1992 and 2011. Because the origin of most of the ice leaving the Laptev Sea by the end of April is situated in the central Laptev Sea in November and not in near-coastal zones, the contribution of polynyas to the winter ice area flux is rather small and limited to events that take place in the vicinity of the Laptev Sea boundaries (for example NS and NET polynyas; see Fig. 1). Hence, ice export during winter months is dominated by ice formed during freeze-up. Nevertheless, ice that is formed in polynyas occupies large portions of the Laptev Sea area at the end of the winter. If the polynya ice is then incorporated into the Transpolar Drift during summer months, or if it becomes subject of melting can not be answered. Too little information is available on the drift of Laptev Sea ice in summer.

\section{Discussion of area flux estimates}

Through a comparison with Envisat and ADCP ice drift information, we have shown that the accuracy of the Ifremer data in the Laptev Sea is high (see Sect. 2). This is in agreement with findings of Rozman et al. (2011). Assuming that the error in the Ifremer ice drift estimates is normally distributed throughout the year, unbiased and uncorrelated, one can calculate the uncertainty in NB and EB ice flux based on the boundary length and the $S E$ of the $V$ and $U$ component (Fig. 2), respectively. For the winter season (October to May) this results in an uncertainty in ice area flux of $8.1 \times 10^{4} \mathrm{~km}^{2}$ and $5.7 \times 10^{4} \mathrm{~km}^{2}$ for the NB and EB, respectively.

The ice exchange of the Laptev Sea with surrounding seas were investigated for the first time by Zakharov (1966a) and Zakharov (1967) using monthly gradients of atmospheric pressure for the period between 1937 and 1958. According to Alexandrov et al. (2000), the authors found the ice exchange between fall and spring to be within the range of our findings. However, the publication is available in Russian only, which makes a direct comparison with our estimates difficult. Sea ice circulation in the Laptev Sea and ice exchange with the Arctic Ocean have been further studied by Alexandrov et al. (2000). The authors investigated ice exchange through the NB and EB based on a large-scale thermodynamic-dynamic sea ice model from 1979 to 1995 . Following Alexandrov et al. (2000), the average winter (October to May) ice flux varies between $2.51 \times 10^{5} \mathrm{~km}^{2}$ and $7.32 \times 10^{5} \mathrm{~km}^{2}$ with a mean value of $4.83 \times 10^{5} \mathrm{~km}^{2}$. Due to the different study period, a quantitative comparison of our flux estimates with model estimates of Alexandrov et al. (2000) is not possible. However, their computations exceed our calculations by approximately $40 \%\left(3.48 \times 10^{5} \mathrm{~km}^{2}\right)$. A direct comparison of data from the three year overlap between the two time series (1992/93-1994/95) indicates an offset of $29 \%$. This number is consistent with the uncertainty in model computations of Alexandrov et al. (2000). Through a comparison of model results with satellite-derived fluxes (SSM/I) for the winter of $1987 / 88$ and 1994/95 the authors could show that their model calculations overestimate observations by as much as $24 \%$.

Overall, our analysis showed that the winter (OctoberMay) total ice area flux out of the Laptev Sea has increased throughout the last two decades. The trend in total ice transport across boundaries is significant at the $95 \%$ confidence level, while the trend in zonal flux across EB is significant only at $90 \% p$. The positive trend of the flux rates across NB is thereby smaller and statistically not significant. The comparison of SLP gradients with ice concentration and acrossboundary ice drift showed that most of the interannual and seasonal variability in the Laptev Sea ice area flux can be linked to changes in geostrophic winds (compare Fig. 7). However, although variations in SLP gradients may explain large fractions of the year-to-year changes in monthly ice transport rates, they do not explain the observed long-term positive trends in area fluxes.

Figure 10 shows the daily anomalies of the pressure gradients for the past $1 \mathrm{yr}$ at NB and EB separately. Trends, which were calculated in a least square sense from these daily anomalies on the original data grids, are negative across both boundaries but not statistically significant. Along the EB the decrease is more pronounced and amounts to approximately $-0.74 \mathrm{hPa} \mathrm{decade}^{-1}$ as compared to $-0.68 \mathrm{hPa} \mathrm{decade}^{-1}$ at the NB. Note that the negative trends in the SLP gradients are also visible in the across-boundary component of the 


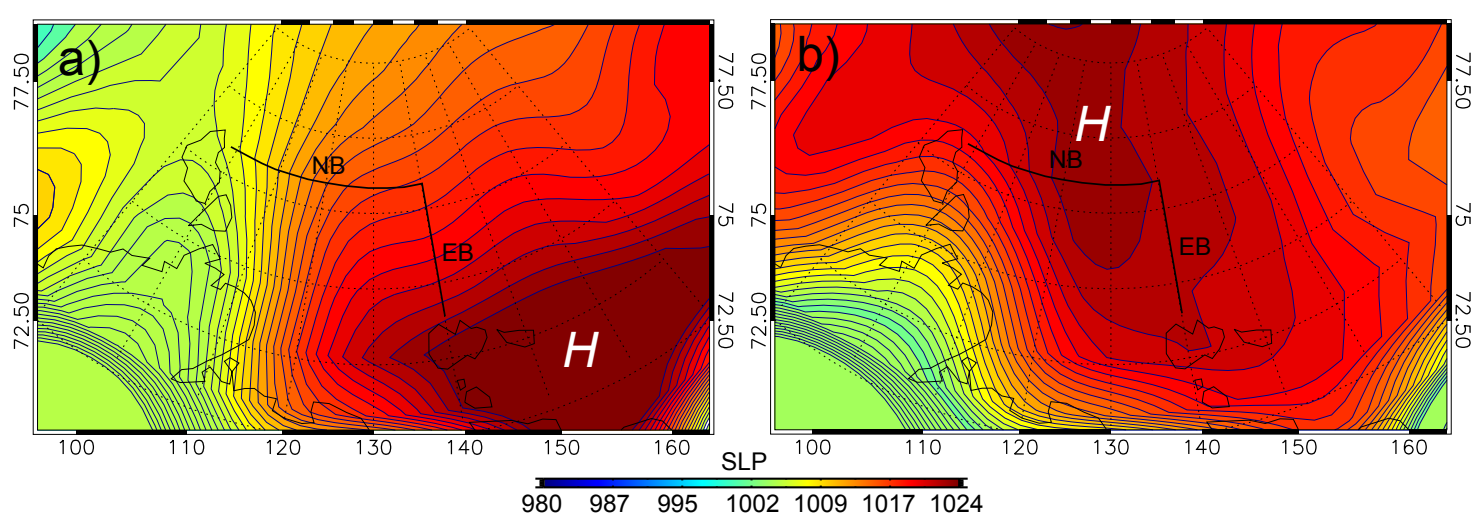

Fig. 9. Origin and drift of sea ice leaving the NB and EB at the end of April as obtained by the back-propagation of ice parcels over a 6-month period (see text for a detailed description). (a) and (b) show ice drift patterns for a winter with high (2008/09) and low (1998/99) ice transportation rates across boundaries. The color represents the position of the sea ice at a specific month before exiting the northern or eastern boundary. The trajectory of sea ice leaving the Laptev Sea through the center of the NB and EB are represented by black lines. (c) shows the frequency of origins (position in November) of sea ice between 1992 and 2011.
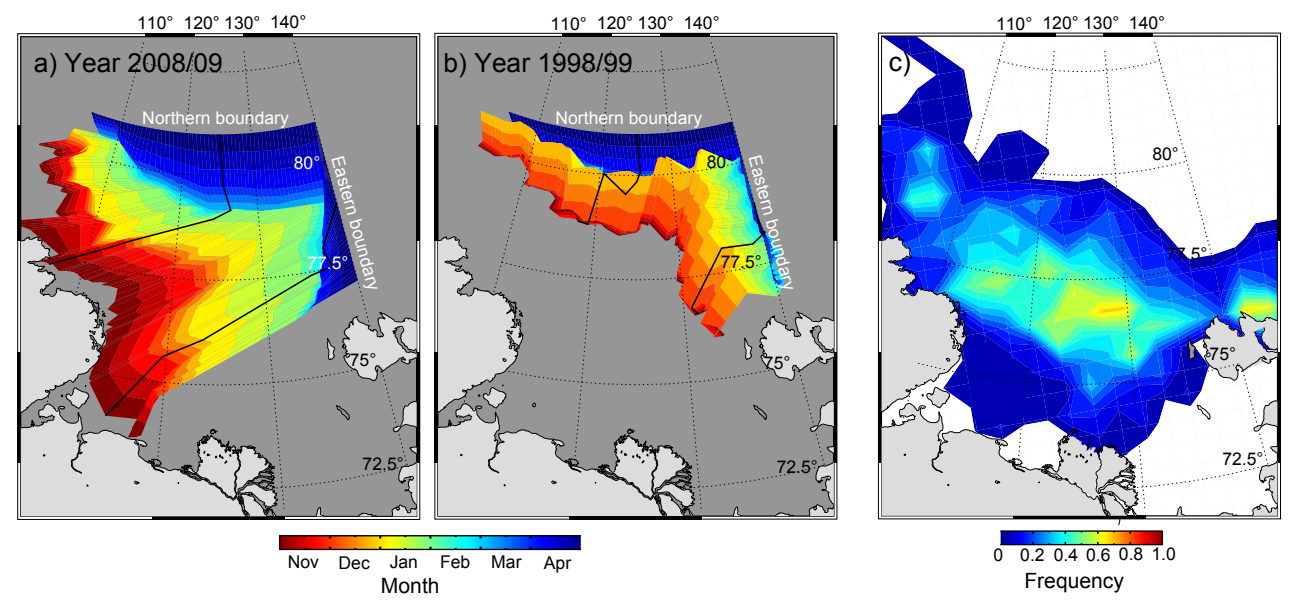

Fig. 10. Time series of Sea Level Pressure (SLP) gradient anomalies (October to May) across the eastern and northern boundaries. The blue line represents the monthly data. The trend line is calculated in a least square sense from the daily anomalies.

wind velocities $(U$ and $V$ ). At the $\mathrm{EB}$, the $U$ component decreases by approximately $-0.56 \mathrm{~m} \mathrm{~s}^{-1}$ decade $^{-1}$, while the NB shows a reduction in $V$ by $-0.50 \mathrm{~m} \mathrm{~s}^{-1}$ decade $^{-1}$ (not shown here). Hence, we conclude that no evidence exists that the increase in ice area flux is favored by an increase in wind speed.

Our results are consistent with findings made by Spreen et al. (2011), who examined spatial trends in Arctic sea ice drift by means of SSM/I satellite data for the winter month of October through May between 1992 and 2009. They found a significant increase in ice drift velocity over large fractions of the Arctic Ocean and in the Laptev Sea. According to the authors, the increase in wind speed in the central Arctic explains a large fraction of the observed increase in drift velocities. However, in other regions, such as the Northern Barents, Kara, Laptev, and East Siberian Seas, wind speed trends are mainly negative and do not correlate with trends in ice motion.

Therefore, other mechanisms may be responsible for the observed changes in ice transport rates throughout the past two decades (in particular across the EB). Along the NB and $\mathrm{EB}$, surface currents are believed to be primarily wind- and ice-driven. Following Spreen et al. (2011) we assume that the increasing ice drift speed and flux rates in the Laptev Sea may be rather associated with a change in the ice cover (thinning and/or decreasing concentration), caused by the rapid loss and thinning of thick multiyear ice (Haas et al., 2008; Kwok and Rothrock, 2009; Comiso, 2012). This is in agreement with Rampal et al. (2009), who found that changing thickness, deformation and compactness of the ice cover are accompanied by an increase in sea ice drift velocities measured by drift-buoys. Because of the absence of a positive 


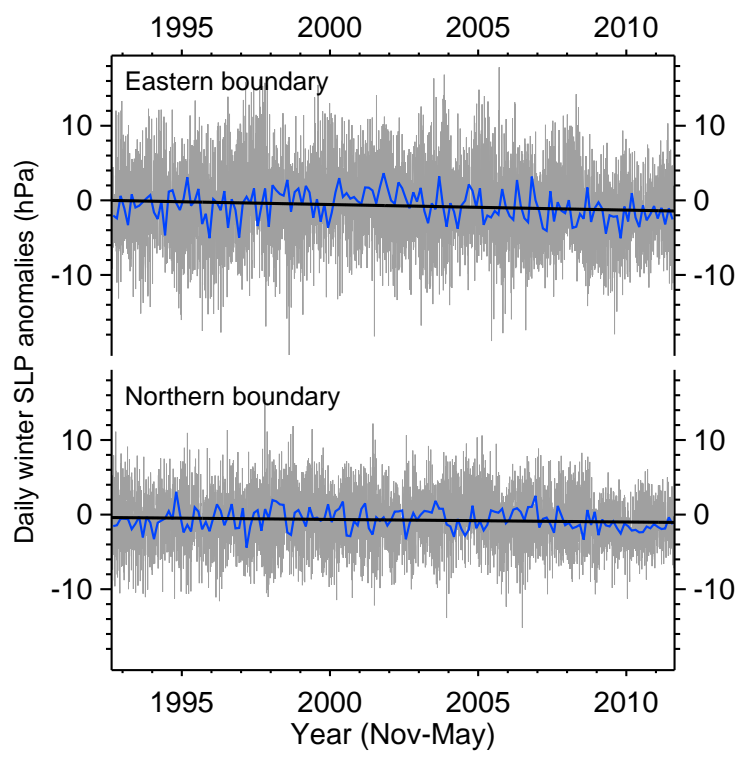

Fig. 11. Time series of winter (December-February) Dipole Anomaly (DA) and Arctic Oscillation (AO) index vs. normalized monthly anomalies of detrended total ice area flux out of the Laptev Sea from 1992 to 2010.

trend in surface wind speed, they concluded that changes in the ice cover play a dominant role in explaining the observed trends in sea ice drift velocities.

\subsection{Linkage between ice area flux and large-scale atmospheric circulation}

Previous studies have shown that changes in Laptev Sea ice drift patterns are linked to changes in the large-scale atmospheric circulation (e.g. Proshutinsky and Johnson, 1997; Alexandrov et al., 2000). Following e.g., Proshutinsky and Johnson (1997) or Deser et al. (2000) the Arctic atmospheric and oceanic circulation regime alternates between an intensified or suppressed cyclonic circulation in the Northern Hemisphere and the Arctic and a weakened or strengthened anticyclonic circulation (Beaufort Gyre). The decadal and multidecadal variability in the atmospheric and oceanic circulation is summarized in the Arctic Oscillation (AO) index, which is defined as the leading principal component of the Northern Hemisphere SLP (Rigor et al., 2002). In this context, Proshutinsky and Johnson (1997) define the two arcticwide observed wind-driven oceanic circulation patterns as the anticyclonic (negative $\mathrm{AO}$ index) and cyclonic (positive $\mathrm{AO}$ index) circulation regime, each of which persists from 5 to $7 \mathrm{yr}$.

A negative coupling between $\mathrm{AO}$ index and winter ice export was observed by Proshutinsky and Johnson (1997) and Alexandrov et al. (2000) between the late 1970s and the early 1990s. According to Proshutinsky and Johnson (1997), during negative AO index phases, ice leaving the Laptev Sea through the northern boundary is directly incorporated into the Transpolar Drift. This phase is characterized by an aboveaverage winter ice area flux through the northern boundary. In contrast, during positive AO phases when the Transpolar Drift is shifted east towards the North American Arctic (Bareiss and Goergen, 2005), most of the sea ice is exported from the Laptev Sea to the East Siberian Sea across the eastern boundary. Alexandrov et al. (2000) who found that the magnitude and direction of Laptev Sea ice exchange with surrounding seas agrees well with the large-scale drift pattern during periods of prevailing anticyclonic or cyclonic circulation. The standardized detrended anomalies of the Laptev Sea ice area flux (December-February) through the northern boundary and the interannual variability of the winter AO index (December-February) are presented for the period from 1992 to 2010 in Fig. 11. However, in contrast to Proshutinsky and Johnson (1997), we find the winter sea ice area flux anomalies in the Laptev Sea to be only weakly correlated with the $\mathrm{AO}$ index $(R=0.24)$.

Wu et al. (2006), Watanabe et al. (2006), and Wang et al. (2009) conclude that the influence of the winter Dipole Anomaly (DA) on the Arctic-wide sea ice motion is greater than that of the winter AO. The DA is defined by the second EOF (Empirical Orthogonal Function) mode of the SLP north of $70^{\circ} \mathrm{N}$. Following Wu et al. (2006), a positive phase of the DA favors a weakening of the Beaufort Gyre, increases sea ice export out of the Arctic basin through the Fram Strait and the northern Barents Sea, and enhances sea ice import from the Laptev Sea and the East Siberian Sea into the Arctic basin. During the negative phase of the DA, the opposite scenario occurs, i.e. the Beaufort gyre is strengthened, more sea ice remains in the western Arctic, and sea ice exports from the Laptev Sea and Kara Sea decreases. A comparison of the DA index phases with our ice area flux estimates reveals that there is indeed a correlation between ice export and the second EOF mode of SLP north of $70^{\circ} \mathrm{N}$ (Fig. 11). However, the correlation is negative $(R=-0.62)$, which stands in contrast to findings of Wu et al. (2006) and Watanabe et al. (2006).

The apparent weak response of ice area flux to AO and DA patterns indicates that no clear linkage exists between Laptev Sea ice circulation, and the large-scale atmospheric circulation. The magnitude of ice flux is rather determined by local atmospheric patterns, such as the occurrence of a high pressure system over the East Siberian Sea, resulting in enhanced ice area flux. Consequently, earlier studies that link other processes such as fast ice extent, polynya activity or freshwater distribution in the Laptev Sea to AO/DA patterns, may require reconsideration, particularly if the linked processes are partially dependent on the sea ice transport/circulation. Nevertheless, one must not forget that large-scale atmospheric patterns only explain a fraction of the SLP variability (Rigor et al., 2002) and that the linkage with ice conditions can be sensitive to the position of the SLP anomalies (Stroeve et al., 2011) that are not captured by EOF loading patterns. 


\subsection{Linkage between ice area flux and summer ice conditions}

The Laptev Sea ice extent is currently undergoing a significant decrease in summer (compare e.g., Fig. 9, sea ice concentration in September along the NB and EB). Following e.g., Bareiss and Goergen (2005), anomalies in summer sea ice extent are thought to be the consequence of i) synopticscale processes (e.g. cyclones) superimposed on the largescale atmospheric circulation during summer, and ii), to a lesser extent, from preconditioning processes in late winter and spring. The connection between shifts in the atmospheric circulation and in particular the role of cyclonicity for anomalies in summer sea ice concentration were previously discussed by Serreze et al. (1993); Serreze (1995); Maslanik et al. (1996) and Maslanik et al. (2000). In particular, cyclones entering the Laptev Sea from the southwest enhance the northward ice transport and are associated with an inflow of anomalous warm air masses of above-average air temperatures, which may contribute to sea ice melt. Persistent low sea level pressure and above-average summer surface air temperatures may further promote early break-up, rapid melt and subsequent reductions in surface albedo as indicated by Haas and Eicken (2001) and Serreze et al. (2003). A detailed discussion on potential linkages between summer ice coverage and atmospheric processes is given in Bareiss and Goergen (2005).

The preconditioning role of winter and spring sea ice processes on the summer and fall ice conditions in the Laptev Sea was investigated by e.g., Deser et al. (2000) and Rigor et al. (2002). Follwing Rigor et al. (2002), positive AO phases coincide with an increase in ice advection away from the fast ice edge, which results in an increase in production of new thin ice in coastal polynyas. The enhanced northward ice drift during positive $\mathrm{AO}$ phases is the consequence of a cyclonic sea ice motion pattern in the Arctic Basin promoting ice divergence in the Eurasian Arctic. The presence of extensive thin ice zones at the end of the winter may in turn favor ice retreat in summer and results in a delayed freeze-up in fall. Likewise, Alexandrov et al. (2000) found that during years where ice export out of the Laptev Sea was above average (e.g. winters of 1992/93 and 1994/95), a below-average summer ice extent could be observed. This implies that negative sea ice anomalies in summer may be caused by enhanced northward ice advection during the previous winter.

The thinning effect of enhanced offshore ice advection on the sea ice cover has recently been observed in field. At the end of April 2012, a sequence of electromagnetic (EM) helicopter-borne ice thickness measurements (Haas and Eicken, 2001) were carried out over the WNS polynya north of the Lena Delta (Fig. 1). The winter of 2011/12 (not included in this study) was characterized by the highest northward advection rates observed since 1992. The continuous ice export away from the fast ice edge led to the development of an almost 200-km-wide thin ice zone of less than

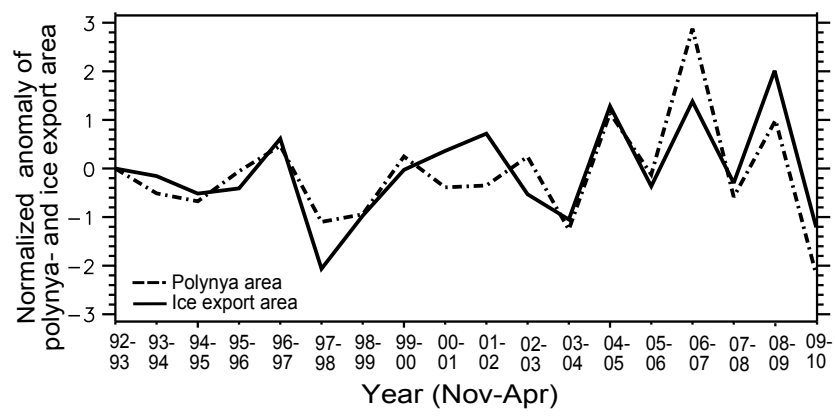

Fig. 12. Normalized anomalies of accumulated polynya area (thin ice and open water, dashed dotted line) and total ice area flux (solid line) between November and April from 1992 until 2009.

$40 \mathrm{~cm}$ ice thickness. In contrast, EM measurements that were made at the end of April 2008 show a substantially different ice regime north of the fast ice edge. A below-average northward ice transport and longer periods of onshore-directed ice drift formed heavily compacted ice more than $1.5 \mathrm{~m}$ thick (Rabenstein et al., 2012). It stands to reason that the presence of extensive thin ice areas at the end of winter, along with continuous offshore transport during early spring and the intrusion of warm air masses from the south, may accelerate ice retreat in summer. In the following, we will focus on the potential linkage that exists between presence/absence of extensive thin ice areas in late winter and the occurrence of low/high summer ice extent.

Thin ice areas can be derived directly from AMSR-E and SSM/I scenes, using the Polynya Signature Simulation Method (PSSM, Markus and Burns, 1995; Kern, 2009; Willmes et al., 2011). The method provides a classification of thin ice and open water (polynya area) and is based on the sensitivity of passive microwave polarization ratios to ice thickness in the range of 0-20 cm (Willmes et al., 2010). However, the coarse spatial resolution of passive microwave satellite data, in particular if applied to narrow polynyas or polynyas formed during extremely cold periods, generates errors through mixed signals at the fast and pack-ice edges, and results in underestimating the thin ice and open water area (Willmes et al., 2010; Krumpen et al., 2011b).

Because offshore wind favors both ice transport away from the coast and the development of thin ice in flaw polynyas, a close relationship exists between across-boundary ice export and estimated polynya area (Fig. 12). The high agreement $(R=0.85)$ allows us to focus on ice export in order to further understand the link between thin ice areas and the subsequent summer ice anomaly. Shown in Fig. 12 are the normalized anomalies of ice export at the NB and EB and polynya area (thin ice/open water) as derived from the PSSM for the period between 1992 and 2009. The PSSM was driven with the daily Advanced Microwave Scanning Radiometer-Earth Observing System (AMSR-E)/Aqua L2A Global Swath Spatially Resampled Brightness Temperatures 


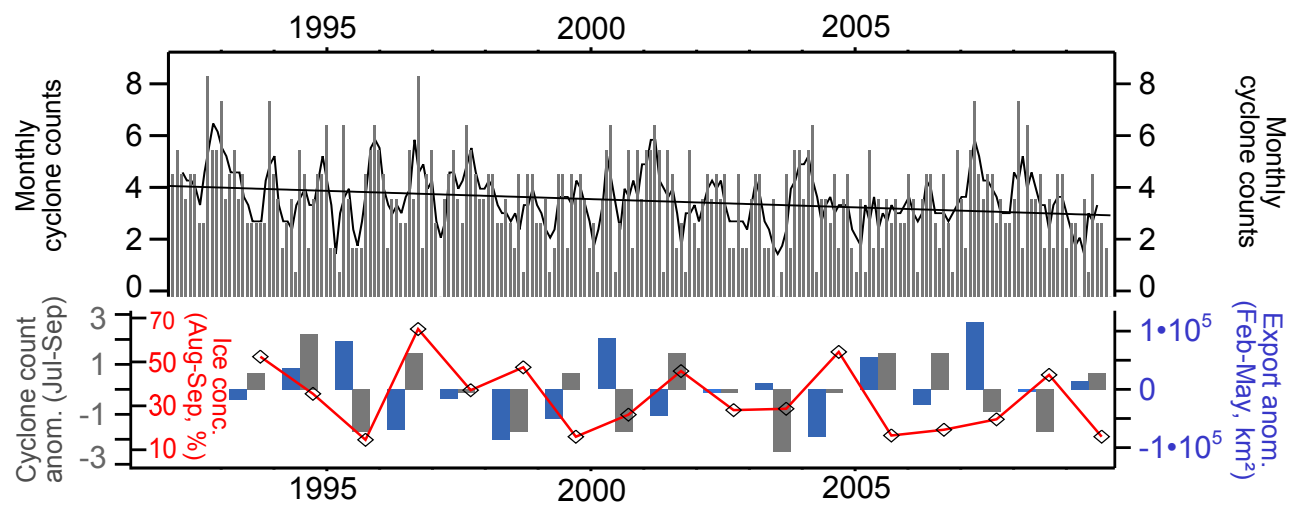

Fig. 13. The upper panel shows the frequency of cyclone counts per month in the Laptev Sea for the period between 1992 and 2009 . The black lines represent the 3 month running mean and the trend. The lower panel presents anomalies in cyclone counts entering the Laptev Sea from the south and west between July and September (grey bar, left axis). The red line shows the average sea ice concentration for August-September (second left axis). Blue bars refer to anomalies in ice area flux out of the Laptev Sea across the NB and EB between February and May (given in $\mathrm{km}^{2}$, right axis).

data set (Ashcroft, 2008), available since 2002. Prior to 2002 the polynya area was deducted from the open water area in specific regions using a polynomial regression model that describes the relation between polynya area (from PSSM with AMSR-E) and SSM/I sea ice concentrations. The model is derived from the data overlapping period (20022008). A detailed description of the methodology is given in Willmes et al. (2011).

The comparison of ice area flux in late winter/early spring with summer ice anomalies of the following summer reveals a negative coupling that support our assumption (Fig. 13, lower panel): there is evidence that an enhanced northward/eastward transport of ice between February and May can result in larger, less deformed, thin ice areas that may more rapidly melt once temperatures rise above freezing. The correlation coefficient between summer ice coverage and winter ice area flux (February to May) is $R=-0.65$. The figure indicates that years of above-average ice export are generally characterized by below-average summer ice extent and vice versa (e.g. 2004 and 2005). Including ice advection that took place before February results in a weaker negative correlation coefficient. Taking into account early summer ice export rates (e.g. June and July) is not possible, owing to the limited temporal coverage of the Ifremer ice drift dataset.

Synoptic scale processes such as cyclones occurring during summer are believed to further accelerate ice retreat and melting (see discussion above). For example, Maslanik et al. (1996) report that an increase in cyclonicity in northern Siberia since 1989 coincides with negative sea ice anomalies in the Laptev Sea during the early 1990s. To confirm this relationship, we derived a time series of cyclone events (region: $100^{\circ}-140^{\circ} \mathrm{E}, 72^{\circ}-79^{\circ} \mathrm{N}$, Fig. 13 , upper panel). The tracking approach is based on the relative vorticity field in the $850 \mathrm{hPa}$ pressure level computed from 6-hourly NCEP reanalysis data. For a detailed method description we refer to
Hoskins and Hodges (2002) and Hodges et al. (2011). The cyclone activity in the Laptev Sea is characterized by a seasonal cycle, with generally lower activity during winter than during summer. The average number of cyclones entering the Laptev Sea per month is approximately 3.9. The trend in cyclone frequency is negative $(-0.67$ cyclones/decade) but not significant.

Following Rademacher (2009), cyclones entering the Laptev Sea from the west, passing $100^{\circ}$ and $120^{\circ} \mathrm{E}$ between $74^{\circ}$ and $79^{\circ} \mathrm{N}$, can be expected to be of greater impact on offshore transport and polynya activity (e.g. T, AL and WNS; Fig. 1). These cyclones cause westerly winds on their southern side and southwesterly winds on their front side. In addition, cyclones entering from the south between $110^{\circ}-135^{\circ} \mathrm{E}$ and $74^{\circ}-78^{\circ} \mathrm{N}$ enhance offshore transport through southerly winds in the central Laptev Sea and southeasterly winds over the New Siberian Islands. Nevertheless, a comparison of northward- and eastward-directed summer cyclone activity with the sea ice minimum in September reveals no evidence of a connection between synoptic scale processes and the summer sea ice situation. Anomalies in the number of easterly and northerly moving cyclones for the period between July and September are given in Fig. 13 (lower panel). This time period was chosen, because after July the sea ice cover becomes vulnerable to cyclone activity and wind stress (Bareiss and Goergen, 2005).

Our results imply that the summer sea ice extent is at least partially controlled by the magnitude of ice area flux during late winter/early spring. The observed positive trends in offshore-directed ice transport (compare Fig. 3), likely being the consequence of a change in the sea ice cover (e.g. thinning/decrease in concentration), may act as a positive feedback, further amplifying an early ice retreat in summer. The absence of a positive coupling between synoptic scale processes and summer sea ice conditions is somewhat 
surprising and indicates that the contribution of cyclones has been overestimated or is not fully understood. We conclude that the physical connection between late winter/early spring ice area flux, synoptic scale processes and ice extent in summer remains unclear. A more detailed analysis is needed that separates thermodynamic effects from dynamic components, which, however, requires the application of a coupled sea ice ocean model and is part of an upcoming study.

\section{Conclusions}

In this paper we investigate fluctuations in seasonal and interannual sea ice area flux across Laptev Sea boundaries and link observed trends to changes in atmospheric forcing mechanisms. The cumulative October to May total ice area flux amounts to $3.48 \times 10^{5} \mathrm{~km}^{2}$. For comparison, this is approximately $48 \%$ of the winter, and $41 \%$ of the annual Fram Strait export. The average transport across the eastern boundary $\left(0.61 \times 10^{5} \mathrm{~km}^{2}\right)$ is generally lower than across the northern boundary $\left(2.87 \times 10^{5} \mathrm{~km}^{2}\right)$. Ice flux rates show a pronounced seasonal cycle with the highest fluxes in November and January. By use of a back-propagation method, we found that most of the ice that is incorporated into the Transpolar Drift originates from the central and western part of the Laptev Sea, while the exchange with the East Siberian Sea is primarily controlled by ice coming from the central and southeastern Laptev Sea. The contribution of polynyas to the winter ice area flux is small and limited to events that take place in the vicinity of the boundaries. The total ice area flux out of the Laptev Sea is undergoing a statistically significant positive trend of $0.85 \times 10^{5} \mathrm{~km}^{2}$ decade $^{-1}$ between 1992 and 2010. The trend in zonal ice area flux across EB is $0.55 \times 10^{5} \mathrm{~km}^{2} \mathrm{decade}^{-1}$. The positive trend in the meridional transport across NB is $0.3 \times 10^{5} \mathrm{~km}^{2}$ decade $^{-1}$ but not statistically significant.

A large fraction of the year-to-year changes in monthly ice transport can be explained by variations in SLP gradients across boundaries. However, there is no evidence of increasing wind velocities that could explain the overall positive trends in ice export. Following Spreen et al. (2011), we therefore assume that changes in ice flux rates may be related to a change in ice cover such as thinning and/or a decrease in concentration. A comparison of ice export rates with $\mathrm{AO}$ and DA patterns indicates that no clear linkage exists between sea ice circulation in the Laptev Sea and large-scale atmospheric circulation. However, there is evidence that years of high ice export in late winter have a thinning effect on the ice cover, which in turn preconditions negative sea ice extent anomalies in summer. The observed positive trend in offshore-directed ice flux may act as a positive feedback, further accelerating early ice retreat in the Laptev Sea. The missing relationship between synoptic and mesoscale processes and summer sea ice conditions is somewhat surprising and indicates that the contribution of cyclones has been overestimated or is not fully understood.

Acknowledgements. This work was carried out as part of the Russian-German cooperation "System Laptev Sea", funded by the BMBF under grant 03G0639A and the Alfred Wegener Institute. We thank the European Commission as part of the project ArcRisk "Arctic Health Risks: impacts on health in the Arctic and Europe owing to climate-induced changes in contaminant cycling" (FP7 GA226534). Envisat satellite data were obtained through ESA Project EO-9429 "The use of Envisat ASAR imagery for generation and validation of Arctic and Antarctic landfast sea ice masks". AMSR-E and SSM/I brightness temperatures were provided by the NSIDC (Boulder, USA). Ice drift information was obtained from CERSAT/Ifremer (Plouzane, France) and NSIDC, respectively. Furthermore, we thank Charles Fowler from the University of Colorado Boulder for providing an updated version of existing NSIDC drift fields and Lars Smedsrud (University of Bergen) for Fram Strait outflow estimates. The authors also very much appreciate helpful comments made by Stefan Hendricks from the Alfred Wegener Institute and Alfred Helbig from the University of Trier. Finally, we thank the two anonymous reviewers and the editor for insightful comments on the manuscript.

Edited by: J. Stroeve

\section{References}

Alexandrov, V., Martin, T., Kolatschek, J., Eicken, H., and M. Kreyscher, Makshtas, A. P.: Sea ice circulation in the Laptev Sea and ice export to the Arctic Ocean: Results from satellite remote sensing and numerical modeling, J. Geophys. Res., 105, 17143-17159, doi:10.1029/2000JC900029, 2000.

Ashcroft, P. and Wentz, F.: AMSR-E/Aqua L2A global swath spatially-resampled brightness temperatures V001, 2002-2008, Tech. rep., Digital media. Boulder, CO: National Snow and Ice Data Center., 2008.

Bareiss, J. and Goergen, K.: Spatial and temporal variability of sea ice in the Laptev Sea: Analysis and review of satellite passivmicrowave data and model results, 1997 to 2002, Glob. Planet. Change, 48, 28-54, doi:10.1016/j.gloplacha.2004.12.004, 2005.

Comiso, J. C.: Variability and Trends of the Arctic Sea Ice Cover: Sea Ice, vol. 2, Wiley-Blackwell, New York, US, 2010.

Comiso, J. C.: Large Decadal Decline of the Arctic Multiyear Ice Cover, J. Climate, 25, 1176-1193, doi:10.1175/JCLI-D-1100113.1, 2012.

Deser, C., Walsh, J., and Timlin, M.: Arctic sea ice variability in the context of recent atmospheric circulation trends, J. Climate, 13, 617-633, doi:10.1175/15200442(2000)013;0617:ASIVIT ¿2.0.CO;2, 2000.

Dethleff, D., Loewe, P., and Kline, E.: The Laptev Sea flaw lead - Detailed investigation on ice formation and export during 1991/1992 winter season, Cold Reg. Sci. Technol., 27, 225-243, 1998.

Eicken, H., Reimnitz, E., Alexandrov, V., Martin, T., Kassens, H., and Viehoff, T.: Sea-ice processes in the Laptev Sea and their importance for sediment export, Cont. Shelf Res., 17, 205-233, doi:10.1016/S0278-4343(96)00024-6, 1997. 
Eicken, H., Dmitrenko, I. A., Tyshko, K., Darovskikh, A., Dierking, W., Blahak, U., Groves, J., and Kassens, H.: Zonation of the Laptev Sea landfast ice cover and its importance in a frozen estuary, Glob. Planet. Change, 48, 55-83, doi:10.1016/j.gloplacha.2004.12.005, 2005.

Emery, W. J., W., F. C., J., H., and Preller, R. H.: Fram strait satellite image-derived ice motions, J. Geophys. Res., 96, 4751-4768, doi:10.1029/90JC02273, 1991.

Ezraty, R., Girard-Ardhuin, F., Piollé, J. F., Kaleschke, L., and Heygster, G.: Arctic and Antarctic Sea Ice Concentration and Arctic Sea Ice Drift Estimated from Special Sensor Microwave Data, Département d'Océanographie Physique et Spatiale, Ifremer, Brest, France and University of Bremen, Germany, 2.1 Edn., ftp://ftp.ifremer.fr/ifremer/cersat/products/ gridded/psi-drift/documentation/ssmi.pdf, 2007.

Fowler, C.: Polar Pathfinder Daily 25 km EASE-Grid Sea Ice Motion Vectors, Tech. rep., National Snow and Ice Data Center., Boulder, Colorado, USA, 2003.

Girard-Ardhuin, F. and Ezraty, R.: Enhanced Arctic sea ice drift estimation merging radiometer and scatterometer data, IEEE Trans. Geosci. Remote Sens., 50, 2639-2648, doi:10.1109/TGRS.2012.2184124, 2012.

Haas, C. and Eicken, H.: Interannual variability of summer sea ice thickness in the Siberian and central Artic under differnt atmospheric circulation regimes, J. Geophys. Res., 106, 4449-4462, doi:10.1029/1999JC000088, 2001.

Haas, C., Pfaffling, A., Hendricks, S., Rabenstein, L., L., E. J., and Rigor, I.: Reduced ice thickness in Arctic Transpolar Drift favors rapid ice retreat, Geophys. Res. Lett., 35, L17501, doi:10.1029/2008GL034457, 2008.

Hodges, K. I., Lee, R. W., and Bengtsson, L.: A Comparison of Extratropical Cyclones in Recent Reanalyses ERA-Interim, NASA MERRA, NCEP CFSR, and JRA-25, J. Climate, 24, 4888-4906, doi:10.3402/tellusa.v64i0.17196, 2011.

Hoelemann, J. A., Kirillov, S., Klagge, T., Novikhin, A., Kassens, H., and Timokhov, L.: Near-bottom water warming in the Laptev Sea in response to atmospheric and sea ice conditions in 2007, Polar Res., 30, 6425, doi:10.3402/polar.v30i0.6425, 2011.

Hoskins, B. J. and Hodges, K. I.: New perspectives on the Northern Hemisphere winter storm tracks, J. Atmos. Sci., 59, 1041-1061, doi:10.1175/1520-0469(2002)059;1041:NPOTNH ${ }_{i} 2.0 . C O ; 2$, 2002.

Janout, M. A., Hölemann, J. A., and Krumpen, T.: Cross-shelf transport of warm and saline water in response to sea ice drift on the Laptev Sea shelf, J. Geophys. Res., in press, doi:10.1029/2011JC007731, 2012.

Kalnay, E., Kanamitsu, M., Kistler, R., Collins, W., Deaven, D., Gandin, L., Iredell, M., Saha, S., White, G., Woollen, J., Zhu, Z., Leetmaa, A., Reynolds, R., Chelliah, M., Ebisuzaki, W., Higgins, W., Janowiak, J., Ropelewski, C., Wang, J., Jenne, R., and Joseph, D.: The NCEP/NCAR 40-year reanalysis project, Bull. Am. Meteorol. Soc., 44, 437-470, doi:10.1175/15200477(1996)077;0437:TNYRP;2.0.CO;2, 1996.

Kern, S.: Wintertime Antarctic coastal polynya area: 1992-2008, Geophys. Res. Lett., 36, 1-5, doi:10.1029/2009GL038062, 2009.

Krumpen, T., Hoelemann, J. A., Willmes, S., Maqueda, M. A. M., Busche, T., Dmitrenko, I. A., Gerdes, R., Haas, C., Hendricks, S., Kirillov, S., Rabenstein, L., and Schroeder, D.: Sea ice production and water mass modification in the eastern Laptev Sea,
J. Geophys. Res., 116, C5, doi:10.1029/2010JC006545, 2011a.

Krumpen, T., Willmes, S., Morales Maqueda, M. A., Gerdes, R., Haas, C., Hoelemann, J., and Schroeder, D.: Evaluation of a polynya flux model by means of thermal infrared satellite observations, Ann. Glaciol., 52, 52-60, doi:10.3189/172756411795931615, 2011b.

Kwok, R.: Outflow of Arctic Ocean Sea Ice into the Greenland and Barents Seas: 1979-2007, J. Climate, 22, 2438-2457, doi:10.1175/2008JCLI2819.1, 2009.

Kwok, R. and Pang, S. S.: Fram Strait sea ice outflow, J. Geophys. Res., 109, 1-14, doi:10.1029/2003JC001785, 2004.

Kwok, R. and Rothrock., D. A.: Variability of Fram Strait ice flux and North Atlantic Oscillation, J. Geophys. Res., 104, 51775189, doi:10.1029/1998JC900103, 1999.

Kwok, R. and Rothrock, D. A.: Decline in Arctic sea ice thickness from submarine and ICESat records: 1958-2008, Geophys. Res. Lett., 36, 1-5, doi:10.1029/2009GL039035, 2009.

Kwok, R., Cunningham, G. F., Wensnahan, M., Rigor, I., Zwally, H. J., and Yi, D.: Thinning and volume loss of the Arctic Ocean sea ice cover: 2003-2008., J. Geophys. Res., 114, C7, doi:10.1029/2009JC005312, 2009.

Markus, T. and Burns, B. A.: A method to estimate subpixel-scale coastal polynyas with satellite passive microwave data, J. Geophys. Res., 100, 4473-4488, doi:10.1029/94JC02278, 1995.

Maslanik, J., Serreze, M., and Barry, R.: Recent decreases in Arctic summer ice cover and linkages to atmospheric circulation anomalies, Geophys. Res. Lett., 23, 1677-1680, doi:10.1029/96GL01426, 1996.

Maslanik, J., Lynch, A., Serreze, M., and Wu, W.: A case study of regional climate anomalies in the Arctic: performance requirements for a coupled model, J. Climate, 13, 383-401, doi:10.1175/1520-0442(2000)013;0383:ACSORC $i 2.0 . C O ; 2$, 2000.

Massonnet, F., Fichefet, T., Goosse, H., Bitz, C. M., PhilipponBerthier, G., Holland, M. M., and Barriat, P. Y.: Constraining projections of summer Arctic sea ice, The Cryosphere, 6, 13831394, doi:10.5194/tc-6-1383-2012, 2012.

Meier, W. N., Stroeve, J., and Fetterer, F.: Whither Arctic sea ice?, A clear signal of decline regionally, seasonally and extending beyond the satellite record, Ann. Glaciol., 46, 428-434, doi:10.3189/172756407782871170, 2007.

Proshutinsky, A. Y. and Johnson, M. A.: Two circulation regimes of the wind-driven Arctic Ocean, J. Geophys. Res., 102, 12493 12514, doi:10.1029/97JC00738, 1997.

Rabenstein, L., Krumpen, T., Hendricks, S., Haas, C., Hoelemann, J., and Koeberle, C.: Thickness distribution and volume production of up to 4 months old polynya sea ice in the Laptev Sea, The Cryosphere Discuss., 7, 441-473, 2013, doi:10.5194/tcd-7-4412013, 2013.

Rademacher, C.: Tracking of synoptic and mesoscale systems in the Siberian Arctic and their impact on the Laptev Sea polynya, Master's thesis, Meteorologisches Institut, Bonn University, Bonn, Germany, 2009.

Rampal, P., Weiss, J., and Marsan, D.: Positive trend in the mean speed and deformation rate of Arctic sea ice, J. Geophys. Res., 114, C5, doi:10.1029/2008JC005066, 2009.

Rigor, I. G. and Colony, R. L.: Sea-ice production and transport of pollutants in the Laptev Sea, 1997-1993, Sci. Total Environ., 202, 89-110, doi:10.1016/S0048-9697(97)00107-1, 1997. 
Rigor, I. G., Wallace, J., and Colony, R.: Response of Sea Ice to the Arctic Oscillation, J. Climate, 15, 2648-2663, doi:10.1175/15200442(2002)015;2648:ROSITT ¿2.0.CO;2, 2002.

Romanov, I. P.: Atlas of Ice and Snow of the Arctic Basin and the Siberian Shelf Seas, Backbone Publishing Company, Fair Lawn, US, 1996.

Rozman, P., Hoelemann, J., Krumpen, T., Gerdes, R., Koeberle, C., Lavergne, T., and Adams, S.: Validating satellite derived and modelled sea-ice drift in the Laptev Sea with in situ measurements from the winter of 2007/08, Polar Res., 30, 7218, doi:10.3402/polar.v30i0.7218, 2011.

Schwegmann, S., Haas, C., Fowler, C., and Gerdes, R.: A comparison of satellite-derived sea ice motion with drifting buoy data in the Weddell Sea, Ann. Glaciol., 52, 103-110, doi:10.3189/172756411795931813, 2011.

Serreze, M.: Climatological aspects of cyclone development and decay in the Arctic, Atmos.-Ocean, 33, 1-23, doi:10.1080/07055900.1995.9649522, 1995.

Serreze, M., Box, J., Barry, R., and Walsh, J.: Characteristics of Arctic synoptic activity, 1952-1989, Meteorol. Atmos. Phys., 51, 147-164, doi:10.1007/BF01030491, 1993.

Serreze, M., Maslanik, J., Scambos, T., Fetterer, F., Stroeve, J., Knowles, K., Fowler, C., Drobot, S., Barry, R., and T.M., H.: A record minimum arctic sea ice extent and area in 2002., Geophys. Res. Lett., 30, 3, doi:10.1029/2002GL0164062003, 2003.

Smedsrud, L. H., Sirevaag, A., Kloster, K., Sorteberg, A., and Sandven, S.: Recent wind driven high sea ice area export in the Fram Strait contributes to Arctic sea ice decline, The Cryosphere, 5, 821-829, doi:10.5194/tc-5-821-2011, 2011.

Spreen, G., Kaleschke, L., and Heygster, G.: Sea Ice Remote Sensing Using AMSR-E 89 GHz Channels, J. Geophys. Res., 113, 1-14, doi:10.1029/2005JC003384, 2008a.

Spreen, G., Kaleschke, L., and Heygster, G.: Sea ice remote sensing using AMSR-E $89 \mathrm{GHz}$ channels, J. Geophys. Res., 113, doi:10.1029/2005JC003384, 2008b.

Spreen, G., Kwok, R., and Menemenlis, D.: Trends in Arctic sea ice drift and tole of wind forcing: 1992-2009, Geophys. Res. Lett., 38, 1-14, doi:10.1029/2011GL048970, 2011.

Stroeve, J. C., Serreze, M. C., Fetterer, F., Arbetter, T., Meier, W., Maslanik, J., and Knowles, K.: Tracking the Arctic's shrinking ice cover: Another extreme September minimum in 2004, Geophys. Res. Lett., 32, 1-4, doi:10.1029/2004GL021810, 2005.

Stroeve, J. C., Maslanik, J., Serreze, M. C., Rigor, I., Meier, W., and Fowler, C.: Sea ice response to an extreme negative phase of the Arctic Oscillation during winter 2009/2010, Geophys. Res. Lett., 38, L02502, doi:10.1029/2010GL045662, 2011.
Stroeve, J. C., Kattsov, V., Barrett, A., Serreze, M., Pavlova, T., Holland, M., and Meier, W. N.: Trends in Arctic sea ice extent from CMIP5, CMIP3 and observations., Geophys. Res. Lett., 39, L16502, doi:10.1029/2012GL052676, 2012.

Timokhov, L. A.: Regional characteristics of the Laptev and the East Siberian seas: climate, topography, ice phases, thermohaline regime, circulation, Berichte zur Polarforschung, 114, 15-32, http://epic.awi.de/26322/1/BerPolarforsch1994144.pdf, 1994.

Wang, J., Zhang, J., Watanabe, E., Ikeda, M., Mizobata, K., Walsh, J. E., Bai, X., and W., B.: Is the Dipole Anomaly a major driver to record lows in Arctic summer sea ice extent?, Geophys. Res. Lett., 36, L05706, doi:10.1029/2008GL036706, 2009.

Watanabe, E., Wang, J., Sumi, A., and Hasumi, H.: Arctic dipole anomaly and its contribution to sea ice export from the Arctic Ocean in the 20th century, Geophys. Res. Lett., 33, L23703, doi:10.1029/2006GL028112, 2006.

Willmes, S., Krumpen, T., Adams, S., Rabenstein, L., Haas, C., Hoelemann, J., Hendricks, S., and Heinemann, G.: CrossValidation of polynya monitoring methods from multi-sensor satellite and airborne data: A case study from the Laptev Sea, Can. J. Remote Sens., 36, 196-210, doi:10.5589/m10-012, 2010.

Willmes, S., Adams, S., Schroeder, D., and Heinemann, G.: Spatiotemporal variability of polynya dynamics and ice production in the Laptev Sea between the winters of 1979/80 and 2007/08, Polar Research, Thematic cluster, climate drivers of the North, The Laptev Sea system, 30, 9571, doi:10.3402/polar.v30i0.5971, 2011.

Wu, B., Wang, J., and Walsh, J. E.: Dipole Anomaly in the winter Arctic atmosphere and its association with Arctic sea ice motion, Journal of Climate, 18, 210-225, doi:10.1175/JCLI3619.1, 2006.

Zakharov, V. F.: The role of flaw leads off the edge of fast ice in the hydrological and ice regime of the Laptev Sea, Oceanology, 6, 815-821, 1966a.

Zakharov, V. F.: Some features of the estimated ice drift in the Laptev Sea (in Russian), Problems of the Arctic and Antarctic, 23, 45-46, 1966b.

Zakharov, V. F.: Change of the Laptev Sea ice cover in relation with the oscillations of the baric field in the Arctic (in Russian), Tr. Arkt. Antarkt. Inst., 257, 52-72, 1967.

Zhang, X. and Walsh, J. E.: Towards a seasonally ice-covered Arctic Ocea: Scenarios from the IPCC AR4 simulations, J. Climate, 19, 1730-1747, doi:10.1175/JCLI3767.1, 2006. 